\title{
MULTITEMPORAL ANALYSIS OF FOREST COVER CHANGE USING REMOTE SENSING AND GIS OF KANHA TIGER RESERVE, CENTRAL INDIA
}

\author{
R. M. Devi ${ }^{1 *}$, B. Sinha ${ }^{2}$, J. Bisaria ${ }^{1}$ and S. Saran ${ }^{3}$ \\ ${ }^{1}$ Indian Institute of Forest Management, Bhopal, India - rinku.devi.fri@gmail.com, jigyasa@iifm.ac.in \\ ${ }^{2}$ Indian Institute of Forest Management, Bhopal, India and Nalanda University, Rajgir, Bihar - bhaskarsinha@hotmail.com \\ ${ }^{3}$ Indian Institute of Remote Sensing, Dehradun, India - sameer@iirs.gov.in
}

Commission V, SS: Natural Resources Management

KEYWORDS: Forest, LULC, Livelihood, Climate Change, Adaptation

\begin{abstract}
:
Forest ecosystems play a key role in global ecological balance and provide a variety of tangible and intangible ecosystem services that support the livelihoods of rural poor. In addition to the anthropogenic pressure on the forest resources, climate change is also impacting vegetation productivity, biomass and phenological patterns of the forest. There are many studies reported all over the world which use change in Land Use Land Cover (LULC) to assess the impact of climate change on the forest. Land use change (LC) refers to any anthropogenic or natural changes in the terrestrial ecosystem at a variety of spatial or temporal scale. Changes in LULC induced by any causes (natural/anthropogenic) play a major role in global as well as regional scale pattern which in turn affects weather and climate. Remote sensing (RS) data along with Geographic Information System (GIS) help in inventorying, mapping and monitoring of earth resources for effective and sustainable landscape management of forest areas. Accurate information about the current and past LULC including natural forest cover along with accurate means of monitoring the changes are very necessary to design future adaptation strategies and formulation of policies in tune of climate change. Therefore, this study attempts to analyze the changes of LULC of Kanha Tiger Reserve (KTR) due to climate change. The rationale for selecting KTR is to have a largely intact forest area without any interference so that any change in LULC could be attributed to the impact of climate change. The change analysis depicted changes in land use land cover (LULC) pattern by using multi-temporal satellite data over a period of time. Further, these detected changes in different LULC class influence the livelihoods of forest-dependent communities. As the study site is a Sal dominated landscape; the findings could be applied in other Sal dominated landscape of central India in making future policies, adaptation strategies and silvicultural practices for reducing the vulnerability of forest-dependent communities.
\end{abstract}

\section{INTRODUCTION}

\subsection{Climate Change and Impact on Forest}

Climate change is one of the most critical challenges confronting the mankind today by inducing additional stress on Earth's climate system. The severity, frequency and uncertainty related to climate change have increased, which is evident in the form of rising temperature, changing rainfall pattern, shift in seasons and rise in sea levels. This, in turn, has impacted various natural resources, like agriculture, water and forest at different spatial and temporal scales all over the world (IPCC, 2007; INCCA, 2014). Furthermore, in particular, poor countries like India are more vulnerable because of their high dependency on ecosystem goods and services and their limited capacity to adapt to a changing climate (Stern Review 2006).

The technical and financial limitations of the developing countries make adaptation even more difficult and challenging especially for poor communities (IPCC, 2014). Among all the sectors, forests are considered as the most valuable natural resources, as it plays a key role in global ecological balance. Forest ecosystems provide a variety of tangible and intangible ecosystem services that support the livelihoods of rural poor. Furthermore, forests have the potential of slowing down the current trend of global warming by sequestering $\mathrm{CO}_{2}$ from the atmosphere and play a major role in the present and projected future carbon budget. Thus, forests are important both for climate change mitigation as well as adaptation point of view. However, the impact of climate change on forests has been recorded in terms of longer growing seasons, distribution of species, biomass and NPP, soil carbon stock, impact on forest plantations, increase in insect and pest attacks and increased frequency of forest fires (Kirschbaum et al., 1996; Chaturvedi et al., 2011, Savita et al., 2017). These changes have negative impacts on the direct and indirect function of forest ecosystems, influencing the ecosystem services, which in turn will affect the livelihood of forest-dependent communities (FAO, 2005).The projected impacts for forests in India indicate that $40 \%$ to $70 \%$ of the forested grids in different states including central India are likely to experience change under a changing climate, resulting in forest die back and loss of biodiversity, which is irreversible (Gopalakrishnan et al., 2011). A large population of tribal communities resides in the central Indian state of Madhya Pradesh, which is highly dependent on natural resources and therefore, likely to be more affected by deteriorating environmental conditions and factors limiting resource availability, making it difficult for them to cope with the changing climate. Under such a situation, it is timely to assess the vulnerability of the forest ecosystems to climate change,

\footnotetext{
${ }^{*}$ Corresponding author
} 
which have a large economic dependence for timber, fuelwood, fodder, medicines and NTFPs. Thus, in this context, the study attempts to analyze the changes of LULC of Kanha Tiger Reserve (KTR) due to climate change with the help of geospatial tools. The rationale for selecting KTR is to have a large intact forest area without any interference so that any change in LULC could be attributed to the impact of climate change. The change detection identified alterations in land use land cover (LULC) patterns by using multi-temporal satellite data over a period of time. Further, vulnerability of forest dependent community is assessed based on these changes identified using both LULC and primary data collected in selected forest fringe villages. The dominant population of these villages mostly belong to Primitive Tribal Groups (PTGs) Gond and Baiga communities who are dependent on forest's natural resources for their livelihoods. The outcomes of this analysis will lead to framing of programs, adaptation strategies and policies related to reducing livelihood vulnerability of forest-dependent communities.

\subsection{Climate Change Vulnerability}

Vulnerability is the degree to which a system is susceptible to, or unable to cope with, impacts of climate change, including climate variability and extremes (Fussel, 2007). The Intergovernmental Panel on Climate Change (IPCC), define it as an integrated measure of the expected magnitude of adverse effects to a system caused by a given level of certain external stressors. Further, vulnerability depends not only on a system's sensitivity but also, on its ability to adapt to new climatic conditions (Watson, et al., 1996). The term 'vulnerability' has been used by various research communities in many different ways, such as those focused on securing livelihoods, food security, natural hazards, disaster risk management, public health, global environmental change, and climate change (Chitale et al., 2014). As per IPCC's definition, vulnerability includes an external dimension, which is represented here by the 'exposure' of a system to climate variations, as well as an internal dimension, which comprises its 'sensitivity' and its 'adaptive capacity' to these stressors. Exposure, sensitivity, and adaptive capacity are inherently linked, and therefore, can be hard to decipher (Gallopin, 2006). Exposure is considered the potential impacts of climate variability and change; sensitivity is the degree to which the rural communities are affected by the exposure; and adaptive capacity is the system's ability to adapt, withstand or recover from the effects of exposure (Fussel and Klein, 2006). Vulnerability encompasses a variety of elements including sensitivity or susceptibility to harm and lack of capacity to cope and adapt" (IPCC, 2014).

\section{METHODOLOGY}

\subsection{Study area}

Kanha Tiger Reserve (KTR) is situated in Mandla district of Madhya Pradesh in central India. This part of Madhya Pradesh is characterized by high forest cover, a tribal-dominated population, and large-scale poverty. The coordinates of the KTR is $22^{\circ} 02^{\prime} 52.6^{\prime \prime} \mathrm{N}$ to $22^{\circ} 25^{\prime} 48.8^{\prime \prime} \mathrm{N}$ latitude and $80^{\circ} 30^{\prime} 09.3^{\prime \prime}$ E to $81^{\circ} 02^{\prime} 48.4^{\prime \prime} \mathrm{E}$ longitude (Fig.1). KTR is divided into buffer and core area with six ranges in each zone. There are total 35 forest villages and 126 revenue villages in the buffer zone of KTR. The climate of the district is the tropical monsoonal type with temperature ranging from $-2^{\circ} \mathrm{C}$ (winter) to $45^{\circ} \mathrm{C}$ (summer). Average annual rainfall is around $1300 \mathrm{~mm}$ with maximum precipitation in monsoon. The forest area is dominated by teak (Tectonagrandis) and sal (Shorea robusta), mixed with other species like haldu (Adina cardifolla) and aonla (Emblica Officinalis). Some of the important NTFPs are tendu leaves (Diospyros melonoxylon), mahua flowers (Madhuca indica) and harra (Terminalia chebula).

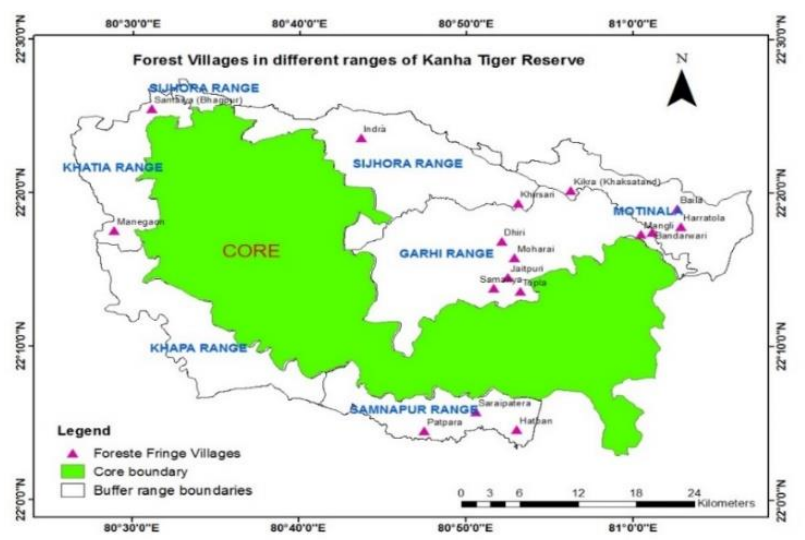

Fig. 1 Map of Kanha Tiger Reserve showing different ranges and forest villages

The district is home to the Primitive Tribal Groups (PTGs) Gond and Baiga communities. As forest fringe villages are more vulnerable due to remoteness, lack of access to modern/commercial energy, poor infrastructure, higher dependency on natural resources and poor socio-economic condition. The communities of the forest fringe area have not been integrated with the mainstream of development, and the impact of climate change makes these communities further vulnerable.

\subsection{Methodology and Sampling Strategy}

The present paper is based on the use of advanced geospatial techniques for understanding the response of vegetation to change in climate at KTR. Analysis of remote sensing data was done by using ArcGIS and ERDAS software. Satellite images of different time period Landsat-5 (1989) and Landsat-8 (2017) of December month (post-monsoon) at spatial resolution of $30 \mathrm{~m}$ was acquired from USGS server. The images were processed, compared and interpreted. Change detection was done by supervised classification, using maximum likelihood classification in ArcGIS 10.3 for calculating the change in forest cover in the buffer zones of KTR. Standard classification by FSI was used for detecting the change in forest cover types i. e. very dense forest with tree cover density of $70 \%$ and above, moderate dense forest $(40 \%$ and more but less than $70 \%$ ), open forest ( $10 \%$ and more but less than $40 \%$ ), non-forest are lands not included in any of the class. Further, for attribution of LULC to climate change, climate data analysis for a common period from 1971-2015 was analyzed. 45 years (19712015 ) is considered adequate enough to observe changes and to establish long-term impacts of climate change. Gridded datasets of IMD at highest resolution $0.25^{\circ} \mathrm{X} 0.25^{\circ}$ (Pai et al., 2014) for precipitation and $1^{\circ} \mathrm{X} 1^{\circ}$ (Rajeevan et al., 2008) for temperature were analyzed and computed at month, season and annual level and was further, analyzed for trend using parametric and nonparametric test statistics. Non-parametric tests include Mann- 
Kendall (MK) (Mann, 1945; Kendall, 1975) test, which is used to confirm the presence of certain suspected trends and then assess the quantum of detected trends if any, was performed in R studio. The next objective was to assess the vulnerability of forest villages to climate change in KTR in order to understand how the local communities of forest villages are affected, their perception and response to climate change and to identify their specific needs for adaptations. The findings from this research will serve as the basis for further analysis to build adaptive capacity in the study sites and in similar areas. Using participatory action research, local community members discussed together climate perturbations they face and exchange on the particularities of past and recent climate-related events. Primary empirical data were collected using household questionnaires. Also, focus group discussions (FGDs) were conducted with villagers to determine recent impacts of heavy and low rainfall on agriculture, livestock and overall livelihoods in the region. FGDs were conducted in different groups based on gender, social background, and primary occupation. The study employs a PRA technique known as "time trend," in which respondents provide an account of their past and discuss how matters close to them have changed over a period of time. This includes perception of climate change on important measures like collection of NTFPs, rainfall trends, temperature trends, agricultural productivity, availability of water, forest fires, regeneration status, phenology, forest cover, coping strategies, awareness and technology support etc. Broadly, important indicators based on vulnerability exposure, sensitivity, adaptive capacity and coping strategy were identified. A total of 22 relevant indicators were identified and were used to assess vulnerability. The different indicators have different units and scales. Therefore, normalization of indicators for scales and units was done by using the methodology similar to the computation of Human Development Index (HDI) based on their functional relationship (positive and negative) between the indicators and vulnerability. Further, the vulnerability index scores of all the 17 selected villages were averaged and Vulnerability index (VI) was calculated for each range in KTR.

\subsection{Multi-stage Sampling Strategy:}

Firstly the clusters of forest ranges were identified. The buffer zone have six ranges with 35 Forest villages. Out of which, representation of each buffer zone was ensured, and more than $50 \%$ of villages were selected to get the maximum representation of forest-dependent population. In the next stage of sampling, a simple random sampling strategy was applied, and about 185 households were interviewed, which is approximately $10 \%$ of the total population of the selected villages (Fig.1). In the preliminary survey, some revenue villages (RV) were also surveyed, and it was observed that, most of the population in revenue village is largely dependent on agriculture, national park-related tourisms and allied sectors and are relatively better off socio-economically than forest villages.

\section{RESULTS AND DISCUSSIONS}

This section is organized under three heads. The first part consists of LULC of the buffer zone to detect the major changes in forest cover types followed by past climate data analysis. Further, vulnerability analysis of forest fringe village of KTR is presented.

\subsection{Land Use Land Cover Change Classification (LULC)}

Changes detected in forest cover for the buffer zone is represented in Fig. 2(a,b). Forest cover types are classified by FSI classification i. e. very dense forest with tree cover density of $70 \%$ and above, moderate dense forest $(40 \%$ and more but less than $70 \%$ ), open forest (10\% and more but less than $40 \%$ ), nonforest are lands not included in any of the class and water body. LULC classification of different forest cover types and pie chart depicting the percentage of change in forest cover types during 1989 and 2017 is represented in Figure 2(a-d).There is a significant decrease in very dense forest from 397315 ha in 1989 to 221053 ha $(15.59 \%$ reduction) during 2017 . This may be due to many factors like human settlement nearby the buffer areas, tourism activities and influenced by other human activities etc. Further, an increase in the moderate and open forest was recorded during 2017 at the cost of dense forest (Fig 2 a-d). Water bodies too showed a decline from the past. Increase in temperature and decrease in precipitation, rainfall days, change in seasonal patterns over a long period of time might be the cause of decline in the water bodies, thus affecting the water resources. The non-forest area has also been reduced slightly recording a decrease of $0.34 \%$ which was 20829 ha in 1989 and recorded a change to 16968 ha during 2017. This could be attributed to plantation activities carried by Forest department in buffer zone. In addition, to understand the changes caused by climate change; past climate data of 45 years is analyzed in the next section.

(a)

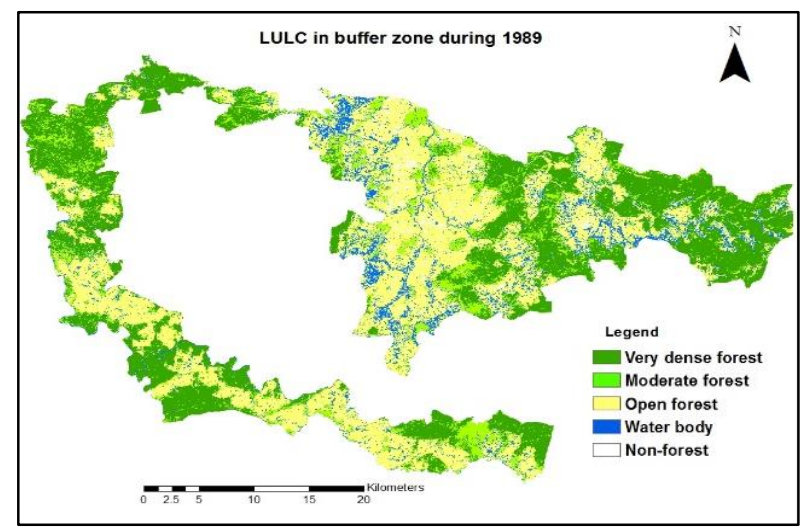

(b)

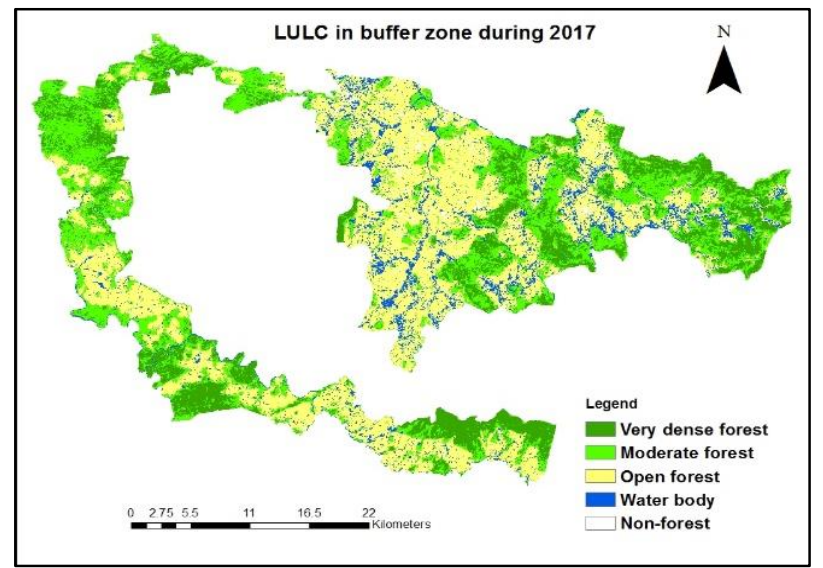


(c)

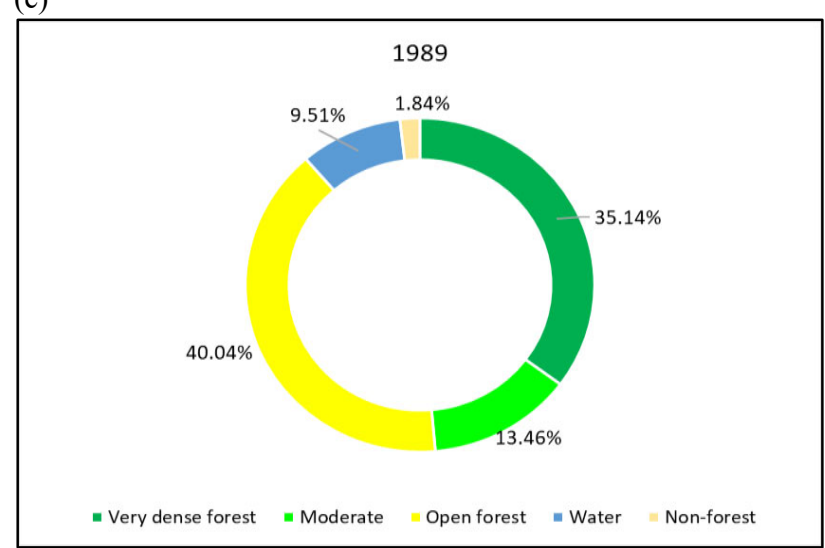

(d)

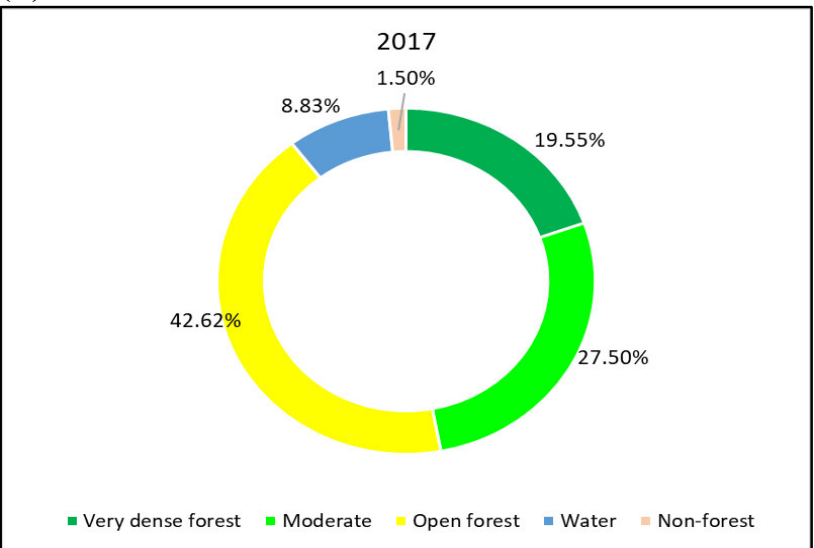

Fig.2 Change in vegetation cover types between (a)1989 and (b) 2017 in the buffer. Percentage of change in different forest cover types during (c)1989 and (d) 2017

\subsection{Analysis of Past Climatic Variables}

Rainfall and temperature are the major climatic variables that indicate climate change in any area. For this study, IMD's rainfall datasets available at $0.25 \times 0.25$ resolution is analyzed on a temporal scale of 45 years (1971-2015). Monthly, seasonal, annual and decadal trends were studied to quantify change at a regional scale. The average annual precipitation has declined in the last 45 years (Fig.3a). Rainfall data was then averaged by seasons. i.e., summer or pre-monsoon i.e. March-May (MAM); monsoon, i.e. June-September (JJAS); post-monsoon, i.e. October-November; Winter, i.e. December-February (DJF). The analysis depicts a significant decline in seasonal precipitation especially in the monsoon and winter months (Fig. 3b). Furthermore, there is a decadal drop of $6.8 \mathrm{~mm}$ in rainfall in the study area $\left(R^{2}=0.02\right)$ over the period of 45 years (Fig. $3 c$ ) along with a significant decline in number of rainy days especially in the last decade (Fig. 3d).

Change (increase or decrease) in temperature over at least three decades in any area is a direct indicator of climate change in the region. IMD's temperature datasets at resolutions $1^{\circ} \times 1^{\circ}$ for a common time period of 45 years (1971-2015) were analyzed to understand monthly, seasonal, annual and decadal trends of mean, maximum and minimum temperature in the study area. [Fig 4 (a-i)]. The linear trend showed an increase in the mean annual temperature (Fig. $4 \mathrm{a}-4 \mathrm{c}$ ) at the rate of $0.036^{\circ} \mathrm{C}$ per annum and $0.368{ }^{\circ} \mathrm{C}$ per decade. The most significant rise in temperature was observed in summer season during 2010 $\left(32^{\circ} \mathrm{C}\right)$.

(a)

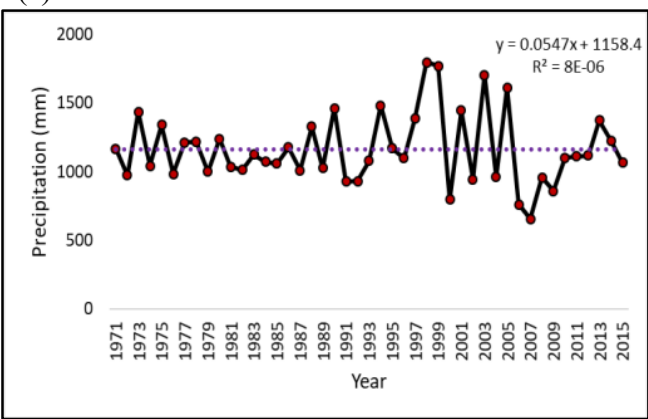

(b)
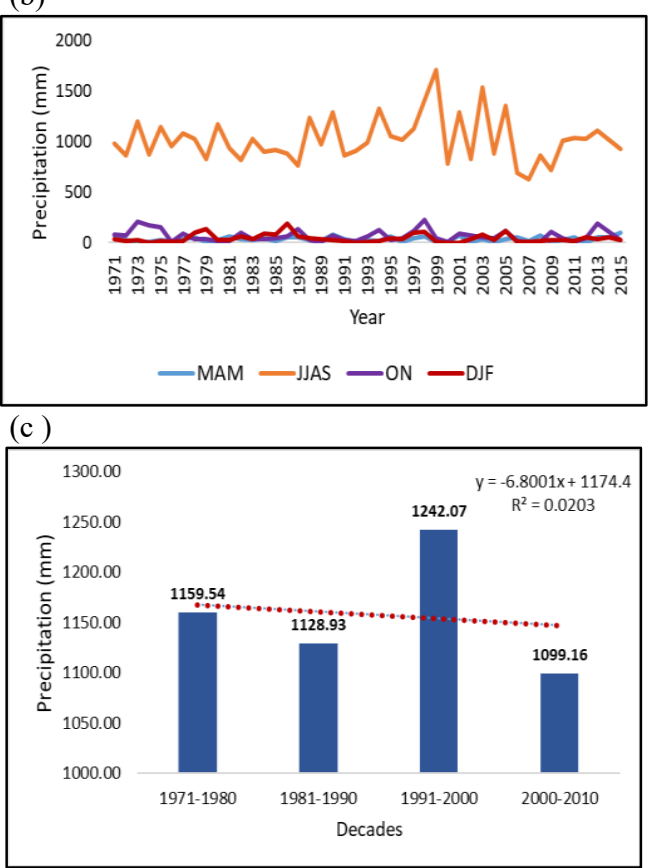

(d)

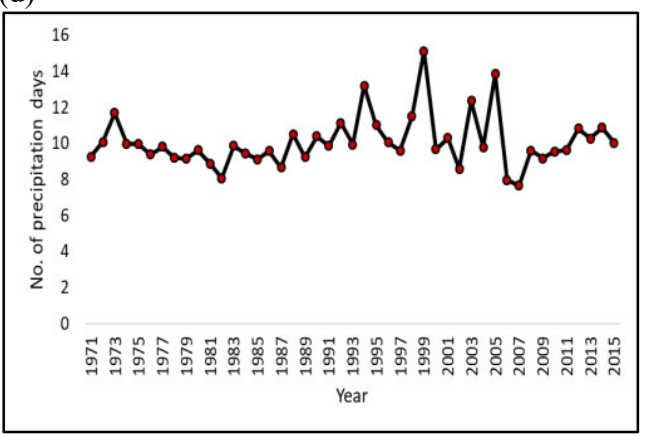

Fig 3. Precipitation trends from 1971-2015 (a) Annual precipitation (b) Seasonal precipitation (c ) Decadal trend (d) Precipitation days 
(a)

MeanT

(d)

MaxT
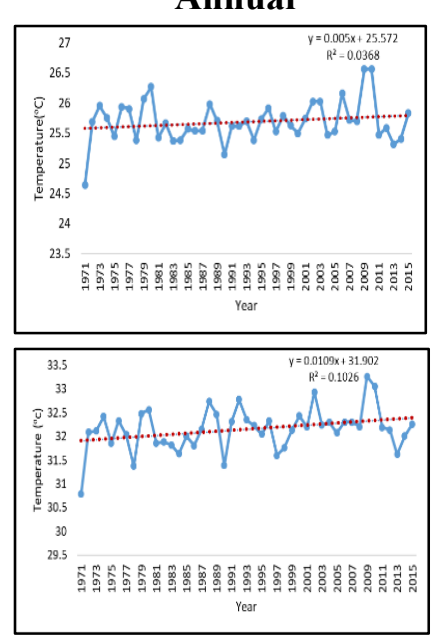

$(\mathrm{g})$

MinT

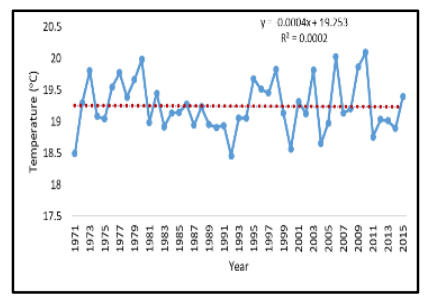

(b)

(e)

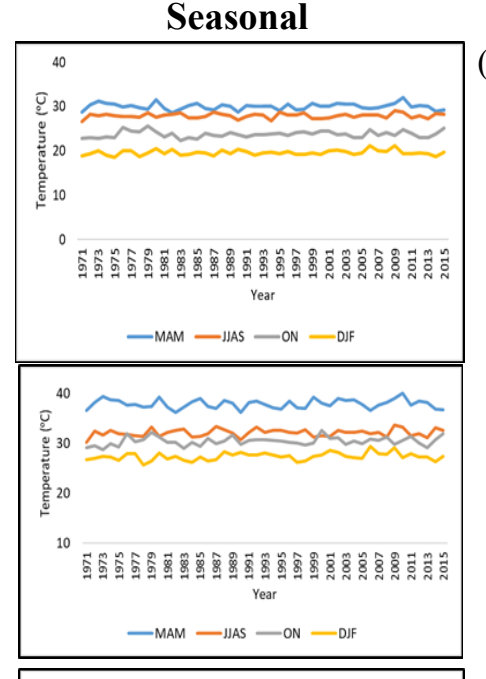

(h)

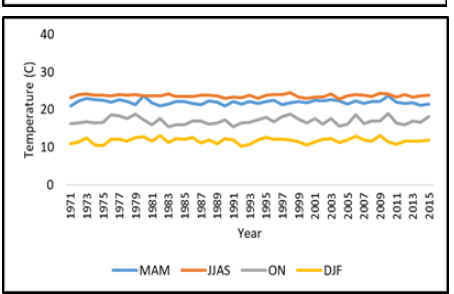

(c)

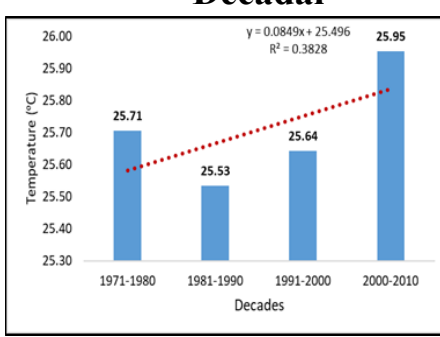

(f)

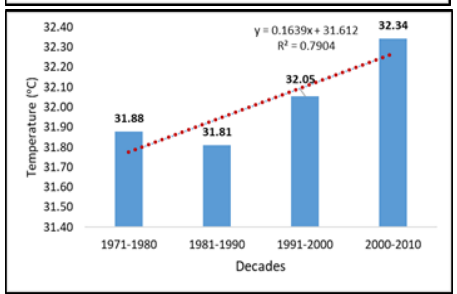

(i)

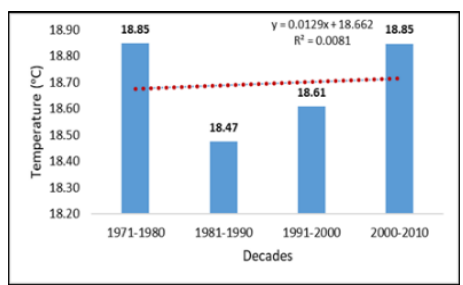

Fig 4. Mean, seasonal and decadal temperature trends from 1971-2015 for MeanT (a-c), MaxT (d-f) and MinT (g-i) respectively

Similarly, in case of MaxT, $0.16^{\circ} \mathrm{C}$ per annum and $0.79{ }^{\circ} \mathrm{C}$ per decade is the increase in MaxT respectively over the 45 years (Fig. $4 \mathrm{~d}$ and $\mathrm{f}$ ). The increase in maximum temperature was also observed during summer month with highest maximum temperature $\left(40.18^{\circ} \mathrm{C}\right)$ during 2010 followed by monsoon temperature $\left(33^{\circ} \mathrm{C}\right)$ (Fig. 4e). The annual and decadal increase of minimum temperature was comparatively less as compared to maximum temperature at the rate of $0.0002^{\circ} \mathrm{C}$ per annum and $0.008{ }^{\circ} \mathrm{C}$ per decade [Fig. 4 (g and i)]. Seasonal increase in minimum temperature was observed during post-monsoon and winter months (Fig. 4h). To further confirm the trend in time series of climate variables, non-parametric test statistic called Mann- Kendall was applied. This test is used to detects the presence of trends in the time series. The null hypothesis underlying the test is: "there is no significant trend within the data series". When the null hypothesis is rejected, it is an indication of a significant trend in the data series, which may be either positive or negative, as described by its $\mathrm{Z}$ and $\mathrm{Q}$ score. A positive value of the test statistic indicates an increasing trend, and a negative value indicates a decreasing trend. The sen's method assumes a linear trend in the time series and has been widely used for determining the magnitude of a trend in time series (Partal and Kahya, 2006). Table 1 depicts the results of MK test (Z) and Sen's estimate (Q).
The entire available data series of precipitation and temperature for the period 1971-2015 was analyzed for trend detection at monthly, annual and seasonal scale using MK test statistic. On analysis of precipitation data series, a negative declining trend of precipitation was observed annually and seasonally over the period of 45 years. On monthly analysis, April $(Z=0.12)$ and July $(Z=2.23)$ months showed a significant positive increase in magnitude, while significant negative magnitude was observed during August ( $Z=-2.21)$ month. In case of temperature data sets, a positive significant increase in temperature was observed for mean and maximum temperature in the stud area. November month showed a significant increase in the trend of the mean $(\mathrm{Z}=1.79)$ and maximum $(\mathrm{Z}=2.22)$ temperatures. Further, a significant increase in temperature trend of December month was observed for maximum temperature data series. In the case of minimum temperature, a significant decrease in temperature $(Z=-1.70)$ was observed during monsoon month. Thus, from all the parametric and non-parametric test revealed an overall decrease in precipitation trend and increase in temperature trend over the 45 years which could be attributed to climate change and affecting the vegetation growth. 
Table 1. Results of statistical test (MK-test and Sen's estimate) for seasonal and annual precipitation over the period 1971-2015 in KTR

\begin{tabular}{|c|c|c|c|c|c|c|c|c|}
\hline & \multicolumn{2}{|c|}{ Precipitation } & \multicolumn{2}{|c|}{ Mean temperature } & \multicolumn{2}{|c|}{ Maximum temperature } & \multicolumn{2}{|c|}{$\begin{array}{c}\text { Minimum } \\
\text { temperature }\end{array}$} \\
\hline & $Z$ & Q & Z & Q & Z & Q & $\mathrm{Z}$ & Q \\
\hline January & -0.13 & 0 & -0.67 & -0.00 & 0.09 & 0.003 & 0.34 & 0.005 \\
\hline February & -0.75 & -0.07 & 1.26 & 0.01 & 0.82 & 0.019 & 0.85 & 0.011 \\
\hline March & 0.76 & 0.07 & 0.21 & 0.00 & 0.03 & 0.002 & 0.65 & 0.007 \\
\hline April & 1.66 & $0.12^{+}$ & -0.99 & -0.01 & -0.14 & -0.003 & -0.40 & -0.006 \\
\hline May & -0.24 & -0.02 & 0.09 & 0.00 & 0.23 & 0.005 & -0.31 & -0.006 \\
\hline June & 0.36 & 0.36 & -0.26 & -0.00 & 0.00 & -0.002 & -1.45 & -0.027 \\
\hline July & 1.65 & $2.23^{+}$ & 0.34 & 0.00 & 1.39 & 0.023 & -0.28 & -0.004 \\
\hline August & -2.37 & $-2.21 *$ & 1.36 & 0.00 & 0.99 & 0.015 & -0.85 & -0.008 \\
\hline September & 0.18 & 0.13 & 1.54 & 0.010 & 0.54 & 0.009 & -0.85 & -0.008 \\
\hline October & -0.47 & -0.27 & -0.13 & -0.00 & 0.31 & 0.006 & -0.65 & -0.012 \\
\hline November & -0.65 & 0.00 & $1.79^{+}$ & 0.02 & $2.22 *$ & 0.041 & 0.34 & 0.010 \\
\hline December & 0.55 & 0.00 & 1.38 & 0.01 & $1.96+$ & 0.032 & -0.77 & -0.016 \\
\hline ANNUAL & -0.04 & -0.25 & 0.66 & 0.00 & 1.28 & 0.010 & -0.82 & -0.007 \\
\hline MAM & 0.90 & 0.22 & -0.32 & -0.00 & 0.11 & 0.002 & -0.14 & -0.002 \\
\hline JJAS & 0.14 & 0.32 & 0.38 & 0.00 & 0.65 & 0.007 & $-1.70+$ & -0.013 \\
\hline ON & -0.79 & -0.55 & 1.52 & 0.01 & 1.08 & 0.020 & 0.03 & 0.000 \\
\hline DJF & -0.34 & -0.12 & 0.95 & 0.00 & 1.16 & 0.016 & -0.26 & -0.003 \\
\hline
\end{tabular}

$\mathrm{Z}=$ Mann-Kendall test, $\mathrm{Q}=$ Sen's slope estimator; "***" Statistically significant trends at $99.99 \%$ significance level; "**" Statistically significant trends at $99 \%$ significance level; "*" Statistically significant trends at $95 \%$ significance level; "+" Statistically significant trends at $90 \%$ significance level

\subsection{Vulnerability assessment}

The study attempted to develop a vulnerability index to assess vulnerability to climate change of forest fringe villages under study in KTR using sector specific indicators. There are 22 major indicators (Table 2) selected through an intensive literature review, followed by a primary survey, participatory rural appraisal, FGDs and consultation with the forest officials. Normalization is done, which is a systematic process of assigning a value to each one of indicator like agricultural land, irrigation, and type of house etc. similar to the approach used to derive Human Development Index (UNDP, 2006; Hahn et al., 2009 and Pandey et al., 2017). Finally, all the different indicators were averaged to form an index corresponding to each main component and vulnerability index of each of the study villages were computed and aggregated at the range level for KTR.

Vulnerability indicators have been partitioned into three dimensions of vulnerability; exposure, sensitivity and adaptive capacity. The first dimension of vulnerability that is exposure includes major components of climate variation, human system and natural resources. Exposure is considered the potential impacts of climate variability and change. Through the process of participatory approach, communities discussed the climate conditions they suffered from, and related impacts of climate change on their livelihoods. Results showed that most important livelihood activities and resources are affected by different climatic disturbances. Changing seasons and droughts represent the highest potential impact on agriculture production, NTFPs, vegetation growth and phenology. Due to increase or decrease in temperature and rainfall pattern, humans are prone to diseases frequently. Further, the natural disasters like drought, frost, fire etc. would affect the natural resources, on which the forest villagers are dependent for their livelihoods.
Most of the respondents expressed that the long drought has directly affected the germination and growth of the crops and forest species leading to the unavailability of some preferred fodder species in the study area. There is a shift in time of mahua (Madhuca indica) flowering, chironji (Buchanania lanzan), aonla (Phyllanthus emblica) and change in leaves of tendu (Diospyros melanoxylon). Thus, the collection of mahua, chironji and tendu are much affected by climate change which further affects the economic condition. Due to an intense increase in temperature, natural forest fires are also observed during summer seasons. Moreover, respondents provide an account of their past and discuss how matters close to them have changed over a period of time. This includes the perception of climate change on important measures like collection of NTFPs, rainfall trends, temperature trends, agriculture productivity, availability of water, forest fires, regeneration status, phenology, forest cover etc. Majority of the respondents found a change i.e. decrease in rainfall trends, rainfall days in comparison to the past 10-15 years. Also, there is an increase in temperature during summer, and winter has shortened. The intensity of frost has increased in recent years, which too could have affected the productivity of crops, regeneration status, phenology, and forest cover. Sensitivity dimension includes components of environment sensitivity, socio-economic, household and climate change sensitivity. Sensitivity is the degree to which the rural communities are affected by the exposure. Altogether, 185 households $(\mathrm{HH})$ were selected for the study, of which $75 \%$ are Gonds followed by Korkus, Baigas, Yadavas and very few belong to general social group. Out of the total $\mathrm{HH}$ sampled, most households were poor, and the majority of these $\mathrm{HH}$ were engaged in agricultural activities and NTFP collection. 
Table 2: Identification of vulnerability indicators

\begin{tabular}{|c|c|c|}
\hline Dimension & $\begin{array}{l}\text { Main } \\
\text { components }\end{array}$ & Indicators \\
\hline \multirow[t]{3}{*}{ a. Exposure } & $\begin{array}{l}\text { Climate } \\
\text { variation }\end{array}$ & Rainfall, temperature \\
\hline & Human system & Disease \\
\hline & Natural system & Drought, frost, fire \\
\hline \multirow[t]{4}{*}{ b. Sensitivity } & $\begin{array}{l}\text { Environment } \\
\text { sensitivity }\end{array}$ & $\begin{array}{l}\text { Crop disease, infertility } \\
\text { of soil, water reduction, } \\
\text { low productivity }\end{array}$ \\
\hline & $\begin{array}{l}\text { Socio economic } \\
\text { sensitivity }\end{array}$ & $\begin{array}{l}\text { Economic class, social } \\
\text { class }\end{array}$ \\
\hline & $\begin{array}{l}\text { Household } \\
\text { Sensitivity }\end{array}$ & $\begin{array}{l}\text { Family size, type of } \\
\text { house, education }\end{array}$ \\
\hline & $\begin{array}{l}\text { Climate change } \\
\text { sensitivity }\end{array}$ & Livestock, agriculture \\
\hline \multirow{8}{*}{$\begin{array}{l}\text { c. Adaptive } \\
\text { capacity/Coping } \\
\text { strategies }\end{array}$} & Social network & Social relationships \\
\hline & $\begin{array}{l}\text { Water } \\
\text { management }\end{array}$ & Water availability \\
\hline & Health & $\begin{array}{l}\text { Disease prevention, } \\
\text { medical facilities }\end{array}$ \\
\hline & $\begin{array}{l}\text { Information } \\
\text { barrier }\end{array}$ & Awareness \\
\hline & Fund support & $\begin{array}{l}\text { Provision of fund or } \\
\text { credit }\end{array}$ \\
\hline & $\begin{array}{l}\text { Material } \\
\text { support }\end{array}$ & $\begin{array}{l}\text { Provision of material } \\
\text { for house }\end{array}$ \\
\hline & Food support & Provision of food \\
\hline & $\begin{array}{l}\text { Information } \\
\text { support }\end{array}$ & $\begin{array}{l}\text { Provision of } \\
\text { information }\end{array}$ \\
\hline
\end{tabular}

Majority of the houses are of kuccha type. Each $\mathrm{HH}$ has an average family size of four-seven members, and some are illiterate and very less educated. Due to climate change, new crop diseases and livestock diseases are increasing and affecting the livelihoods of people. Further, use of fertilizers and pesticides has increased affecting the soil fertility, which ultimately reduces the productivity and quality of crops. Additionally, climate change affects the phenology of forest produce, which directly affects the economy of forest-dependent people. Besides, the water levels have declined in various water sources such as rivers, ponds, and wells. There is scarcity of water, especially during the period of- seedbed preparation, flowering stage of the maize, paddy, irrigating wheat and other crops.

Adaptive capacity is the system's ability to adapt, withstand or recover from the effects of exposure. The social network, water management, health and information barrier are included in the dimension of adaptive capacity. The social relationships of the people are fair enough and help each other in case of emergency. Due to the remoteness of the villages, financial help and medical health facilities are not available inside, but have to cover long distances for reaching medical and markets. There is no drinking water facility in the village and villagers have to go up to one $\mathrm{km}$ to fetch it. No irrigation facilities are available. Most of the agriculture is rain fed. Further, due to poor information network people are less aware and more vulnerable.

Vulnerability encompasses a variety of elements including sensitivity or susceptibility to harm and lack of capacity to cope and adapt. Therefore, coping strategy is important to recover from the unfavorable situations. This includes fund support, material support, food support and information support. Results from the survey suggest that, there is a lack of formal credit mechanisms but informal support is extended to the needy through informal interactions with panchayats. There is support from government agencies for building houses. Also, subsidized food is distributed via PDS. Medical professional from health center also visits the remote villages and distributes medicines freely to needy villagers. Some NGOs also visit the villages and spread awareness about programs and new schemes. Forest Department also provide a compensation for the loss of livestock by wild animals, besides, providing labour jobs to local people and small facilities to $\mathrm{HH}$. Using above indicators a vulnerability index is computed and details are presented in the next section.

\subsection{Vulnerability index range wise and village wise}

The status of Buffer Zone is not that of a National Park and is a multiple use area with various land use patterns, including Reserved Forest, Revenue Land, Orange Area and Private Land. There are six ranges in the buffer zone of KTR namely Garhi, Khatia, Motinala, Samnapur, Sijhora and Khapa. There are total 35 forest villages in buffer ranges except for Khapa which have only revenue villages. The elevation varies from 450 to $940 \mathrm{~m}$. There are numerous natural and artificial water sources present in the buffer zone along with important rivers like Halon which flows through the Garhi and Sijhora forest ranges and its tributaries provide water to forest fringe villages.

Range and village wise vulnerability index is computed and represented in Table 3. The most vulnerable ranges are Garhi (0.63), Samnapur (0.63), Motinala(0.62) followed by Sijhora (0.59) and Khatia (0.59). Motinala, Garhi and to some extent Sijhora range are on higher elevation with slopes ranging from $23^{\circ}$ to $40^{\circ}$. The accessibility to these ranges are not easy and have to cover around $180-280 \mathrm{~km}$ from Khatia range, which is main buffer center place of KTR. Among villages, Samaria forest village of Garhi range and Baila of Motinala range are highly vulnerable. This may be due to remoteness and absence of facilities. Moreover, most of the primitive tribal groups are dominated in these region. They are heavily dependent upon the forest resources, with a touch of aboriginality, they command a strong bearing on natural ecosystems. Baigas are amongst the oldest inhabitants, primitive and interesting forest tribal of this region. Generally, the Baigas take to the bewar (shifting cultivation type), $a$ form of cultivation that consists of 2 to 3 acres of dense forests, chosen usually on a very steep slope. They cut down the entire standing forest crop and burn it in the high summer. Later, in the rains, this ash scattered field is sown with the seeds of marginal crops such as kodon, Kutki, Baiganitur or sweet potatoes (Tiger Conservation Plan, KTR, 2014).

Table 3. Range wise and village wise Vulnerability index 


\begin{tabular}{|c|c|c|}
\hline Range & Villages & $\begin{array}{l}\text { Vulnerability } \\
\text { index }\end{array}$ \\
\hline \multirow[t]{7}{*}{ Garhi } & Dhiri & 0.64 \\
\hline & Japipuri & 0.64 \\
\hline & Khirsadi & 0.64 \\
\hline & Mohrai & 0.59 \\
\hline & Samaria & 0.67 \\
\hline & Topla & 0.62 \\
\hline & AverageVI & 0.63 \\
\hline \multirow[t]{3}{*}{ Khatia } & Manegaon & 0.58 \\
\hline & Samaiyabhagpur & 0.59 \\
\hline & AverageVI & 0.59 \\
\hline \multirow[t]{6}{*}{ Motinala } & Baila & 0.69 \\
\hline & Banderwari & 0.54 \\
\hline & Harratola & 0.64 \\
\hline & Kikra & 0.64 \\
\hline & Mangli & 0.59 \\
\hline & Average VI & 0.62 \\
\hline \multirow[t]{4}{*}{ Samnapur } & Hatwan & 0.65 \\
\hline & Patpara & 0.61 \\
\hline & Saraipatero & 0.62 \\
\hline & Average VI & 0.63 \\
\hline \multirow[t]{2}{*}{ Sijhora } & Indra & 0.59 \\
\hline & Average VI & 0.59 \\
\hline
\end{tabular}

In case, the rains are good in subsequent years; the field will provide excellent crops until the fourth or fifth year. After this, the owner will abandon the field for a new one. Though, the Baigas believe that the forest grows denser after the abandonment of a bewar, much damage is inflicted on the existing forests. Further, Gonds and Bhils are also found in these ranges whose livelihood are totally dependent on forest resources. They cultivate two millets known as Kodo or Kutki. On the other hand, Khatia and Sijhora ranges are slightly developed and have good accessibility in comparison to Garhi, Samnapur and Motinala and have lower elevations and slopes $\left(0^{\circ}\right.$ to $\left.11.3^{\circ}\right)$, which is suitable for agriculture. Moreover, most of the village people are engaged in small works related to the national park, tourism-related activities and other allied sectors. Markets and other facilities are present nearby Khatia, as it is the centre of attraction for the tourists. A similar case is with Samnapur range due to its good accessibility and development of nearby places which makes them less vulnerable.

\subsection{Adaptation strategies adopted by forest villagers}

Though, people have poor knowledge on the technical matters of climate change, they recall several evidences, which demonstrate that they have perceived, felt and experienced its effects. They always had to develop and implement individual and collective strategies to adapt to climate variability and environmental change. Much of the significant adaptation practices are still based on the indigenous knowledge.

In order to escape from continuous crop failure owing to unusual rain and frequent droughts, people are forced to seek some alternatives; like, people used to transplant hybrid-paddy quiet earlier; otherwise it would be affected by insecticides and pests. Thus, farmers have to shift the sowing period of different crops. Late cultivation of paddy may hamper the cultivation season of wheat and mustard. Some people had started to raise the fodder species in their agricultural lands due to unavailability of fodder species in the nearby forest. Some of the households also use biogas as an alternative to firewood, and in few villages, solar street lights were also available as a renewable source of energy. In the case of livestock, more milk yielding livestock are popular as selling milk is quite easier due to market linkages and reasonable price due to Govt. schemes. People have group approach to reclaim the degraded lands for fodder promotion, income generation activities through cash crops and community plantation through community forestry approach.

Further, it has been observed that the water in ponds, wells, canals are getting reduced gradually. Moreover, people have to travel long distances for fetching water. Some ponds had a problem of siltation while others are either encroached or have dried up. But now with the realization of importance of traditional ponds, people are building awareness on rejuvenation and protection of traditional ponds. Through the initiation of community forest user groups, peoples are engaged in the conservation and maintenance of water ponds to harvest monsoon rain to solve the issue of water.

\section{CONCLUSION}

The study concludes a significant change in important climate drivers i.e. precipitation and temperature in the study region. All the parametric and non-parametric test revealed an overall decrease in precipitation and increase in temperature over 45 years. This change in local climate has impacted forest cover, phenology, species structure and composition etc. Satellite image of different time period also detected the change in forest cover types in buffer zone of KTR. There is a decrease in very dense forest type $(15.59 \%)$, water bodies, non-forest area and increase in moderate $(14.04 \%)$ and open forest $(2.57 \%)$.

Furthermore, vulnerability assessment was done in order to understand the local perception, adaptation and coping strategies of the local communities of forest villages affected from climate change. Garhi, Samnapur, Motinala are the most vulnerable ranges followed by Sijhora and Khatia. This could be due to remoteness, lack of access to modern/commercial energy, poor infrastructure, higher dependency on natural resources, illiteracy and poor socio-economic condition. Also, the communities of the forest fringe area have not been integrated with the mainstream of development, and further, the impact of climate change makes these communities more vulnerable. The findings from this research will serve as the basis for further analysis to build adaptive capacity and framing policies. Future work will 
include identification and quantification of additional vulnerability indices and detailed vulnerability assessment of forest fringe villages especially in the context of their dependence on forest resources.

\section{ACKNOWLEDGEMENTS}

We thank the Director, Indian Institute of Forest Management, Bhopal for providing the necessary facilities and infrastructure for the study. We also thank our colleagues for their valuable inputs and encouragement.

\section{REFERENCES}

Chaturvedi, R. K., Gopalakrishnan, R., Jayaraman, M., Bala, G., Joshi, N. V., Sukumar, R., \&Ravindranath, N. H. 2011. Impact of climate change on Indian forests: a dynamic vegetation modeling approach. Mitigation and adaptation strategies for global change, 16(2), 119-142.

Chitale, V. S., Shrestha, H. L., Agarwal, N. K., Choudhurya, D., Gilani, H., Dhonju, H. K., \& Murthy, M. S. R. 2014. Forest climate change Vulnerability and Adaptation Assessment in Himalayas. International Archives of Photogrammetry, Remote Sensing and Spatial Information. Sciences., XL-8, 1291-1294.

Edenhofer, O. et al., Climate Change: Mitigation of Climate Change. Contribution of Working Group III to the Fifth Assessment, Report of the Intergovernmental Panel on Climate Change, Cambridge University Press, Cambridge, United Kingdom, 2014.

Food and Agriculture Organization (FAO). 2005. Adaptation of forest ecosystems and the forest sector to climate change. Forests and Climate Change Working Paper No. 2, Rome, FAO/Swiss Agency for Development and Cooperation.

Fussel, H.M. 2007. Adaptation planning for climate change: concept, assessment approaches and key lessons. Integrated Research System for sustainability Science 2(2): 265-275.

Füssel, H. M., \& Klein, R. J. 2006. Climate change vulnerability assessments: an evolution of conceptual thinking. Climatic change, 75(3), 301-329.

Gallopín, G. C. 2006. Linkages between vulnerability, resilience, and adaptive capacity. Global environmental change, 16(3), 293-303.

Gopalakrishnan, R., Jayaraman, M., Bala, G. and Ravindranath, N. H., Climate change and Indian forests.2011. Current. Science, 101(3), 348-355.

Hahn, M. B., Riederer, A. M., \& Foster, S. O. 2009. The Livelihood Vulnerability Index: A pragmatic approach to assessing risks from climate variability and change-A casestudy in Mozambique. Global Environmental Change, 19(1), 74-88.

INCCA., Indian Network for Climate Change Assessment. Report 2. Climate Change and India: A 4x4 Assessment - A sectoral and Regional Analysis for 2030s, Ministry of Environment and Forest, Government of India. November, 2010.

Kendall, M.G. 1975. Rank Correlation Methods. Charles Griffin: London, UK.

Kirschbaum, M. U. 1996. Climate change impacts on forests. Climate Change 1995-Impacts, adaptations and mitigation of climate change.

Mann, H.B. 1945. Nonparametric tests against trend. Econometrica 13: 245-259.

Pai, D.S., Sridhar, Latha., Rajeevan, M., Sreejith, O.P., Satbhai, N.S., Mukhopadhyay, B. 2014. Development of a new high spatial resolution $\left(0.25^{\circ} \times 0.25^{\circ}\right)$ long period $(1901-2010)$ daily gridded rainfall dataset over India and its comparison with existing datasets over the region. Mausam, 65(1):1-18.

Pandey, R., Alatalo, J. M., Thapliyal, K., Chauhan, S., Archie, K. M., Gupta, A. K., \& Kumar, M. 2018. Climate change vulnerability in urban slum communities: Investigating household adaptation and decision-making capacity in the Indian Himalaya. Ecological Indicators, 90, 379-391.

Rajeevan ,M., Bhate, J., Jaswal, A.K. 2008 Correction to analysis of variability and trends of extreme rainfall events over India using 104years of gridded daily rainfall data. Geophysical Research Letters, 35:L23701.

Sharma, S. K., Singh, H., \& Singh, O. 2017. Forest Fire: A Review. Indian Forester, 143(8), 719-728.

Stern, D. I., \& Cleveland, C. J. 2004. Energy and economic growth. Encyclopedia of energy, 2, 35-51.

Tiger Conservation Plan of Kanha Tiger Reserve. Madhya Pradesh Govt, 2014.

UNDP. 2006. Human development report, United Nations Development Program. Available at: http://hdr.undp.org/hdr2006/statistics/.

Watson, R. T., Zinyowera, M. C., \& Moss, R. H. 1996. Climate change 1995. Impacts, adaptations and mitigation of climate change: scientific-technical analyses. 